\title{
A multi-journal partnership to highlight joint first-authors of manuscripts
}

\author{
M Bishr Omary, ${ }^{1}$ Michael B Wallace, ${ }^{2}$ Emad M El-Omar, ${ }^{3}$ Rajiv Jalan, ${ }^{4}$ \\ Michael $\mathrm{H}$ Nathanson ${ }^{5}$
}

Our journals came together to put forth a plan that highlights joint first-authors in citations that are part of the references section of original articles. This has already been implemented by some of us (Gastroenterology, ${ }^{1}{ }^{2}$ Hepatology $^{3}$ ) but is now part of the Instructions to Authors in all five partnering journals (Gastroenterology, Gastrointestinal Endoscopy, Gut, Hepatology, and Journal of Hepatology). Prior to this, we and most, if not all, other journals highlighted joint first-authors of articles they published on the first page of the article (though such acknowledgment is sometimes difficult to note in some journals). In practical terms, our plan implies that citations listed in the references section will use either bold lettering or an underline to highlight all joint first-authors of a listed reference (as an example, see Reference 1).

There are several reasons for coming together and featuring this policy in a commentary that is jointly published in all five journals. For one, we are delighted to collaborate on timely and relevant initiatives, disseminating information and goals that are of common interest and of benefit to our field, readers, and authors. For example, sometimes we jointly publish clinical guidelines or In Memoriams to honour an esteemed colleague. Secondly, we anticipate that if enough journals incorporate our plan into their author guidelines, it will provide the necessary encouragement for bibliographic databases, such as PubMed, to include highlighting joint first-authors in citations they list using tools within their means (eg, underlining, bold lettering, unique font or color). If we and other journals are able to do so then bibliographic database warehouses are likely to be in a similar position. Already, a prominent cell biology journal, Molecular Biology of the Cell, recently decided to highlight joint first-authors in the reference section of the manuscripts it publishes, ${ }^{4}$ similar to what we describe herein.

The rationale for introducing this minor but relevant aspect to the presentation of citations is abundantly clear-team

${ }^{1}$ Editor, Gastroenterology; ${ }^{2}$ Editor, Gastrointestinal Endoscopy; ${ }^{3}$ Editor, Gut; ${ }^{4}$ Editor, Journal of Hepatology; ${ }^{5}$ Editor, Hepatology

Correspondence to M Bishr Omary; mbishr@umich.edu research and team science (be it basic/fundamental or clinical) have become commonplace in many studies. The percent of publications that include joint first-authors has increased dramatically during the past 15 years for clinically-oriented papers, and during the past 25 years for basic science papers, from nearly zero to $15 \%$ in clinical journals and from less than 3\% up to $37 \%$ for basic science journals. ${ }^{5}$ Hence, et al, is nowadays becoming more than just everyone else aside from the first author. Currently, readers cannot distinguish, in the citations of a reference list, whether two and in some cases more authors (who are otherwise buried in the et al part of a 'Jones et al' study) shared first authorship.

We believe that the effort that goes into highlighting joint first-authors, as part of preparing the manuscript for submission to publication, is rather trivial. Cited manuscripts should be read, or at least examined in some detail that is beyond simply gleaning over the abstract and making a decision whether to cite or not. With this in mind, it would then be simple to know which authors, if any, shared first authorship. Notably, to date, the feedback that has been received from our authors has been very positive and supportive. Given that some effort is needed by our authors to carry out what we propose, we have not required this policy for manuscripts other than original papers, though including such acknowledgments in other manuscript types (eg, reviews, commentaries) is welcome and, in fact, is being done automatically by some of our authors.

We recognise that our journals have different styles of presenting citations, with some asking to list only the first three authors for citations that include more than three authors. This raises the question as to how to proceed when more than three individuals share first authorship. The answer, in such situations, is to highlight all joint first-authors. In the great majority of cases, the number of joint first authors is rarely more than three, though one extreme case in the manuscript "Accuracy of aortic annular measurements obtained from threedimensional echocardiography, CT and MRI: human in vitro and in vivo studies" published in Heart (volume 98, pages 1146-52) included all of the 11 authors as equal contributors.

It is hoped that other journals will decide to incorporate this policy into their author guidelines. Journal editors and publishers of bibliographic databases are in an excellent position to implement such recognition, to help ensure the acknowledgment of researchers who share first place in a body of work that can sometimes take several years to complete. We do not address the issue of equal contribution of corresponding (or even middle) authors, but this is an aspect that can also be covered by the bibliographic databases. At this stage, we focused on the joint first-authors who, typically, are trainees and contributors to the majority of published work.

Editor's Note This commentary is being published simultaneously in the February 2015 issues of the five journals (listed alphabetically): Gastroenterology, Gastrointestinal Endoscopy, Gut, Journal of Hepatology, and Hepatology. The editors of the five journals collaborated equally on this effort and in that sense can be considered co-first authors. We wish to thank Dr Glenn Eisen, past editor of Gastrointestinal Endoscopy, for his initial involvement and support of this effort.

(C) 2015 by the AGA Institute, the American Society for Gastrointestinal Endoscopy, BMJ Publishing Group Ltd and British Society of Gastroenterology, American Association for the Study of Liver Diseases, and European Association for the Study of the Liver.

This article is being published jointly in Gastroenterology, Gastrointestinal Endoscopy, Gut, Hepatology, and Journal of Hepatology.

Acknowledgements We thank our managing editors for helping facilitate the joint publication of this commentary in our five journals. All authors contributed equally to this effort.

Competing interests None.

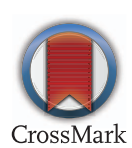

To cite Omary $\mathrm{MB}$, Wallace $\mathrm{MB}$, El-Omar EM, et al. Gut 2015;64:189.

Accepted 21 November 2014

Gut 2015;64:189. doi:10.1136/gutjnl-2014-308880

\section{REFERENCES}

1 Dubnansky E, Omary MB. Acknowledging joint first-authors of published work: the time has come. Gastroenterology 2012;143:879-80.

2 Gastroenterology Instructions for Authors. http://www. gastrojournal.org/content/authorinfo (accessed Oct 2014).

3 Hepatology Author Guidelines. http://onlinelibrary. wiley.com/journal/10.1002/(ISSN)1527-3350/ homepage/ForAuthors.html (accessed Oct 2014).

4 Drubin DG. MBoC improves recognition of co-first authors. Mol Biol Cell 2014;25:1937.

5 Conte ML, Maat SL, Omary MB. Increased co-first authorships in biomedical and clinical publications: a call for recognition. FASEB J 2013;27:3902-4.

Author names in bold designate shared co-first authors. 


\section{GUT A multi-journal partnership to highlight joint first-authors of manuscripts}

M Bishr Omary, Michael B Wallace, Emad M El-Omar, Rajiv Jalan and Michael $\mathrm{H}$ Nathanson

Gut 2015 64: 189

doi: 10.1136/gutjnl-2014-308880

Updated information and services can be found at:

http://gut.bmj.com/content/64/2/189

\section{These include:}

References This article cites 3 articles, 2 of which you can access for free at: http://gut.bmj.com/content/64/2/189\#BIBL

Email alerting

Receive free email alerts when new articles cite this article. Sign up in the service box at the top right corner of the online article.

\section{Notes}

To request permissions go to:

http://group.bmj.com/group/rights-licensing/permissions

To order reprints go to:

http://journals.bmj.com/cgi/reprintform

To subscribe to BMJ go to:

http://group.bmj.com/subscribe/ 